\title{
Characterization of Cellulosic Fibers by FTIR Spectroscopy for Their Further Implementation to Building Materials
}

\author{
Viola Hospodarova, Eva Singovszka, Nadezda Stevulova* \\ Institute of Environmental Engineering, Technical University of Košice, Košice, Slovakia \\ Email: ${ }^{\star}$ nadezda.stevulova@tuke.sk
}

How to cite this paper: Hospodarova, V., Singovszka, E. and Stevulova, N. (2018) Characterization of Cellulosic Fibers by FTIR Spectroscopy for Their Further Implementation to Building Materials. American Journal of Analytical Chemistry, 9, 303-310.

https://doi.org/10.4236/ajac.2018.96023

Received: April 16, 2018

Accepted: June 3, 2018

Published: June 6, 2018

Copyright $\odot 2018$ by authors and Scientific Research Publishing Inc. This work is licensed under the Creative Commons Attribution International License (CC BY 4.0).

http://creativecommons.org/licenses/by/4.0/

\begin{abstract}
Nowadays, the material recycling is a growing trend in development of building materials and therefore using of secondary raw materials for production new building materials is in accordance with sustainable development in civil engineering. Therefore, it is increasingly becoming crucial to accelerate the transition from application of non-renewable sources of raw materials to renewable raw materials. One fast renewable resource is natural plant fibers. The use of the cellulosic fibers as environmentally friendly material in building products contributes to the environmental protection and saves non-renewable resources of raw materials. Wood fibers and recycled cellulose fibers of waste paper appear as suited reinforcing elements for cement-based materials. In this paper, there is used application of Fourier transform infrared spectroscopy (FTIR) on cellulose fibers coming from different sources. FTIR spectra of cellulose fiber samples are investigated and compared with reference sample of cellulose.
\end{abstract}

\section{Keywords}

Renewable Raw Materials, Cellulose Fibers, Infrared Spectroscopy

\section{Introduction}

The last few decades have revealed the growing interest of industry and scientists in the research and development of composite materials based on organic materials originating from renewable sources. Lignocellulosic biomass has become a promising alternative source of raw materials for industrial applications because the main component-cellulose in most plants is inexhaustible [1]. Cellulose as one of the most important polysaccharides in the plant cell wall is widely used in 
the paper industry [2]. A large amount of cellulosic waste is generated yearly by the agro-industries [3].

Increasing importance of cellulosic materials utilization is due to their numerous advantageous properties for application in sustainable building constructions. Therefore, it is increasingly becoming crucial to accelerate the shift from classical to environmentally friendly materials, and so to contribute to the transition to equitable, sustainable, post fossil-carbon societies [4]. In this context, there are efforts centered upon bio-based economy based on sustainable production and consumption of renewable biological resources, as well as their conversion into bio-based products and energies. It is the possible way of achievement of sustainable development in the construction industry to shift from the limited and finite material resources to easily renewable raw material resources. The utilization of biomass in industry as a major strategic approach of 21 st century is mainly focused on the development bio-based building materials. Eco-builders are interested in the utilization of natural biomass resources and recycled waste related materials/products contributing to regulation of the indoor moisture content and to greater levels of indoor air quality [5].

Ligno/cellulosic fibers obtained from biomass are attractive for their application into because of their positive environmental impact [2]. But cellulosic fibers obtained from wood are also a unique material reinforcing the cement composites. They are non-hazardous, renewable and readily available at relatively low cost compared to other commercially available fibers [6]. Due to the increasing scarcity of wood resources, the research is mainly concentrated on the utilization of cellulosic fibers obtained from waste paper as a possible and valuable resource of fibers for preparation sustainable building materials. From this point of view, recycled cellulosic fibers offer the economic advantage that can also reduce the environmental impact risks of primary production of fibers. This trend of incorporation of recycled cellulosic fibers and combination of natural and/or recycled fibers into composites with inorganic matrix is at the center of attention of researchers [7] [8] [9]. Maximizing their use in building materials and improving their performance can be achieved through properties characterization of cellulosic fibers by using adequate methods in order to reveal their chemical composition and physical properties because the composites require a strong fiber with good adhesion between matrix and fiber to enhance their final properties [6].

Fourier transform infrared spectroscopy (FTIR) is one of the most commonly used methods for identification different functional groups constituting a compound. FTIR is a rapid and non-destructive technique for the qualitative and quantitative determination of biomass components in the mid-IR region [10]. FTIR spectroscopy provides information about molecular fragments, the presence or absence of specific functional groups and can give an even deeper insight into the fibers structure. FTIR with ATR unit allows attenuation of the incident radiation and provides IR spectra without the water background absorbance [11]. 
The aim of this paper is comparative FTIR investigation of cellulosic fibers from wood pulp and recycled waste.

\section{Materials and Method}

\subsection{Materials}

Two kinds of cellulose fibers from different processing (wood processing-the sulphate bleached beech tree cellulose; GW500, W640 and G250WT) and (recycling waste paper as newspapers, magazines, and cartons; G500T, G700T and G3/00T) were provided by Greencel Ltd (Hencovce, Slovakia). Figure 1 illustrates represent samples of each kind of cellulosic fibers that are different in color (white-bleached wood pulp) and (grey-recycled fibers).

Six samples of cellulose fibers were tested. Their physical and chemical properties are shown in Table 1. Average fiber length as well as width was measured by L\&W Fiber Tester (Lorentzen \& Wettre, Sweden). Around 20,000 fibers were measured from each pulp in each test (the tests were performed in triplicate). Aspect ratio is characterized as ratio of average fiber length to width. Dry matter was $93 \%$ in all samples except G250WT sample. $\mathrm{pH}$ value of samples ranges from 6 to 7.5 .

The first set of samples featured with high content of holocellulose and low lignin and ash content compared to recycled fibers. Chemical analysis of components of cellulosic fibers is described in our previous paper [12]. As comparative material for FTIR study was used synthetic microcrystalline cellulose.

\subsection{Method}

Infrared spectroscopy combined with the ATR technique (Attenuated Total Reflectance) is ideal for the investigation of the IR of solids without any sample preparation. ATR spectroscopy, also known as internal reflection spectroscopy, is a versatile and non-destructive technique that can be used to measure the IR-spectrum. To perform the analysis, the sample is placed in contact with the

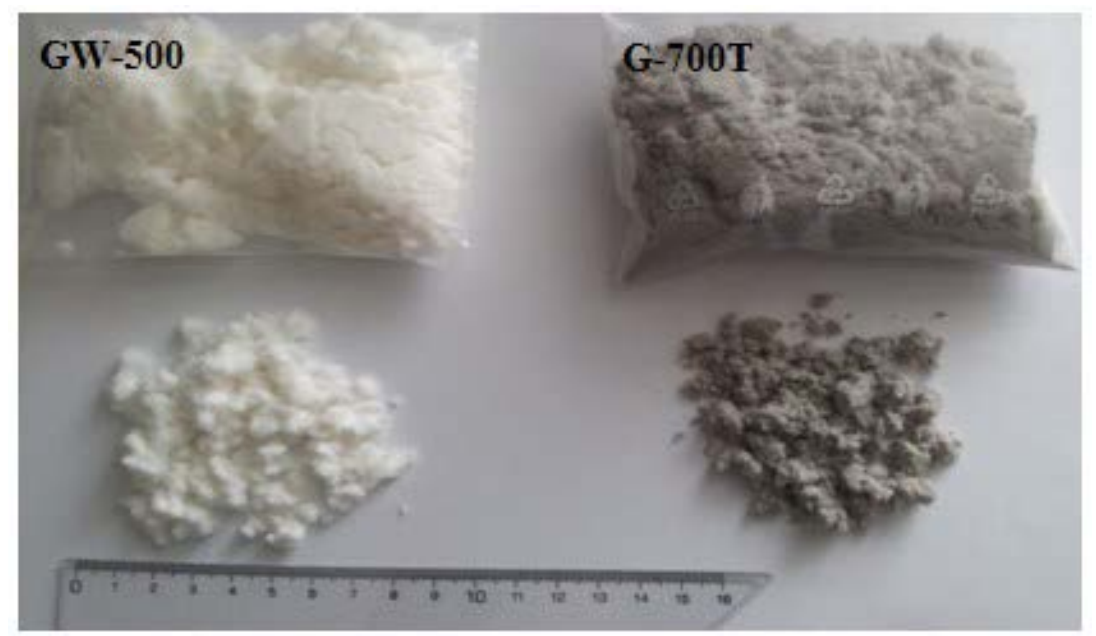

Figure 1. Greencel cellulosic fibers: white wood pulp and grey recycled fibers. 
Table 1. Physical and chemical properties of cellulose fibres.

\begin{tabular}{|c|c|c|c|c|c|c|c|c|c|}
\hline \multirow[b]{2}{*}{$\begin{array}{l}\text { Cellulose } \\
\text { Samples }\end{array}$} & \multicolumn{9}{|c|}{ Properties of Cellulose Fibers } \\
\hline & $\begin{array}{c}\text { Bulk } \\
\text { density } \\
{\left[\mathrm{kg} / \mathrm{m}^{3}\right]}\end{array}$ & $\begin{array}{c}\text { Max. } \\
\text { length } \\
{[\mu \mathrm{m}]}\end{array}$ & $\begin{array}{c}\text { Average } \\
\text { fiber length } f \\
{[\mu \mathrm{m}]}\end{array}$ & $\begin{array}{c}\text { Average } \\
\text { fiber width } \\
{[\mu \mathrm{m}]}\end{array}$ & $\begin{array}{c}\text { Aspect } \\
\text { ratio }\end{array}$ & $\begin{array}{c}\text { Holocellulose } \\
{[\%]}\end{array}$ & $\begin{array}{c}\text { Cellulose } \\
\text { [\%] }\end{array}$ & $\begin{array}{c}\text { Lignin } \\
{[\%]}\end{array}$ & $\begin{array}{l}\text { Ash } \\
{[\%]}\end{array}$ \\
\hline GW500 & $60-80$ & 500 & 504 & 21.7 & 23.2 & 99.11 & 81.99 & 0.42 & 0.08 \\
\hline W640 & $35-45$ & 1000 & 640 & 21.3 & 30.0 & 99.67 & 80.49 & 0.05 & 0.21 \\
\hline G250WT & $80-100$ & 500 & 514 & 21.8 & 23.6 & 99.09 & 62.13 & 0.12 & 12.11 \\
\hline G500T & $50-100$ & 400 & 556 & 29.5 & 18.8 & 71.03 & 47.40 & 17.05 & 19.91 \\
\hline G700T & $40-70$ & 600 & 701 & 30.9 & 22.7 & 71.98 & 46.95 & 20.05 & 22.80 \\
\hline G3/00T & $30-50$ & 1200 & 796 & 29.0 & 27.5 & 81.30 & 56.97 & 20.11 & 16.54 \\
\hline
\end{tabular}

surface of an IR transmitting crystal. The IR light is reflected from the inside surface of the crystal, but it penetrates a small distance into the sample and is therefore partially absorbed.

No sample preparation is needed and the only requirement being that the sample is in intimate contact with the crystal surface.

FTIR spectra of cellulose fibres from wood pulp and recycled fibres were obtained on an Alpha Bruker Platinum-ATR spectrometer in the range from 4000 $\mathrm{cm}^{-1}$ to $400 \mathrm{~cm}^{-1}$ at a resolution of $4 \mathrm{~cm}^{-1}$. A total of 24 scans were taken for each sample. The spectra of samples were compared with microcrystalline cellulose (MC).

\section{Results and Discussion}

FTIR spectra of cellulose fibers from wood pulp and recycled waste paper are compared with reference sample in Figure 2 and Figure 3. The absorption bands are observed in two wave number regions of $3660-2800 \mathrm{~cm}^{-1}$ and 1650 $400 \mathrm{~cm}^{-1}$. The presence of peaks on the spectra of cellulose samples coming from wood pulp corresponds to bands of microcrystalline cellulose (Figure 2), while differences in absorption bands intensities and appearance of new peaks in spectra of recycled cellulosic fibers are observed.

Identification of the absorption bands is following. The observed peaks in the wave number range of $3660-2900 \mathrm{~cm}^{-1}$ is characteristic for stretching vibration of $\mathrm{O}-\mathrm{H}$ and $\mathrm{C}-\mathrm{H}$ bonds in polysaccharides. The broad peak at $3331 \mathrm{~cm}^{-1}$ is characteristic for stretching vibration of the hydroxyl group in polysaccharides [3] [13]. This peak includes also inter- and intra-molecular hydrogen bond vibrations in cellulose [14]. The band at $2894 \mathrm{~cm}^{-1}$ is attributed to $\mathrm{CH}$ stretching vibration of all hydrocarbon constituent in polysaccharides [3] [13]. Typical bands assigned to cellulose were observed in the region of $1630-900 \mathrm{~cm}^{-1}$. The peaks located at $1633 \mathrm{~cm}^{-1}$ correspond to vibration of water molecules absorbed in cellulose [3] [13]. The absorption bands at 1428, 1367, 1334, $1027 \mathrm{~cm}^{-1}$ and 896 $\mathrm{cm}^{-1}$ belong to stretching and bending vibrations of $-\mathrm{CH}_{2}$ and $-\mathrm{CH},-\mathrm{OH}$ and $\mathrm{C}-\mathrm{O}$ bonds in cellulose [10] [15]. The band at around $1420-1430 \mathrm{~cm}^{-1}$ is 


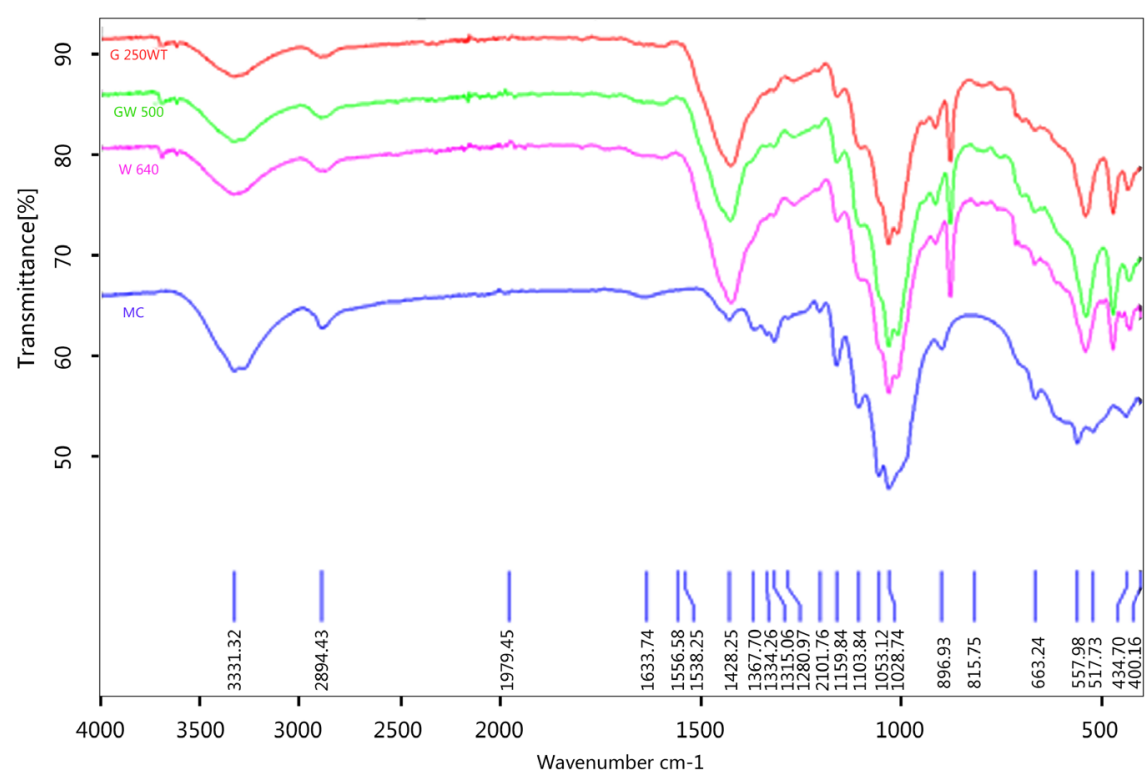

Figure 2. FTIR spectra of wood pulp cellulose fibers compared to microcrystalline cellulose (MC).

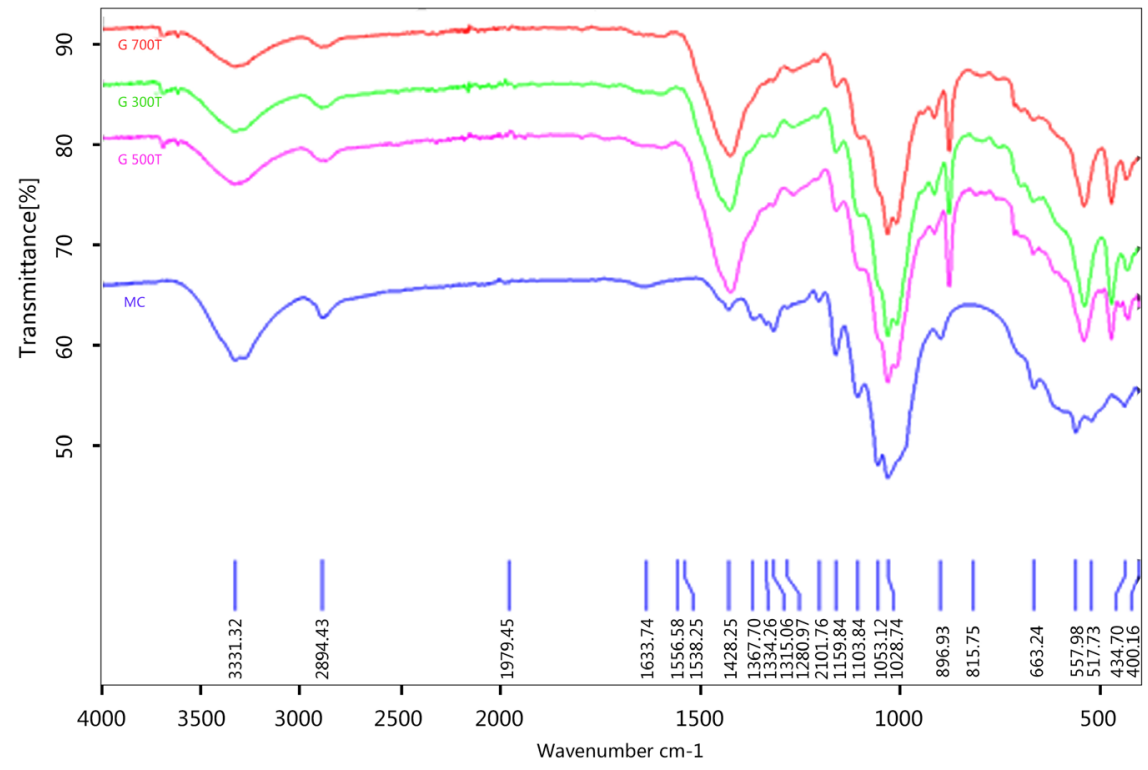

Figure 3. FTIR spectra of recycled cellulose fibers compared to microcrystalline cellulose (MC).

associated with the amount of the crystalline structure of the cellulose, while the band at $897 \mathrm{~cm}^{-1}$ is assigned to the amorphous region in cellulose [1].

In Figure 2, visible differences were noted in the spectrum of G250WT sample. There are changes in intensities of the signals at $1428 \mathrm{~cm}^{-1}, 896,875 \mathrm{~cm}^{-1}$ and $712 \mathrm{~cm}^{-1}$. A broad peak at $1428 \mathrm{~cm}^{-1}$ includes $-\mathrm{CH}_{2}$ and $\mathrm{CH}$ bonds vibrations coming from cellulose as well as the vibration of $\mathrm{C}=\mathrm{O}$ bonds in the carbonate ion $\left(\mathrm{CO}_{3}{ }^{2-}\right)$. The $\mathrm{CO}$ bond vibrations in pure $\mathrm{CaCO}_{3}$ are visible at 1475 $\mathrm{cm}^{-1}$. The weak intensity peaks at 875 and $712 \mathrm{~cm}^{-1}$ also belong to $\mathrm{C}=\mathrm{O}$ bonds in 
carbonate anion. The FTIR spectra of the cellulosic fiber samples from waste paper in Figure 3 are very similar to spectrum of G250WT sample (Figure 2). This fact implies the presence of calcium carbonate [11] in cellulose samples as impurity deriving from the used filler in paper making what corresponds to cellulose purity (Table 1). However, further new peaks attributed to kaolinite in the spectra of recycled fibers were observed. The structure of this aluminosilicate mineral is two-layered, one silicon-oxygen tetrahedral layer $\left(\mathrm{SiO}_{4}\right)$ joined to $\mathrm{Al}(\mathrm{O}, \mathrm{OH})_{6}$ octahedral layer or expressed in other way, $\left[\mathrm{Si}_{2} \mathrm{O}_{5}\right]_{2}$-layer and $\left[\mathrm{Al}_{2}(\mathrm{OH})_{4}\right]_{2}$-layer with pseudo-hexagonal symmetry [16]. The four absorptions at $3697,3669,3645$ and $3620 \mathrm{~cm}^{-1}$ are typical for kaolinite spectrum (amount aluminum in octahedral). The band at around $3620 \mathrm{~cm}^{-1}$ has been ascribed to the inner hydroxyls, and the peaks at around the other three characteristic wave numbers are generally attributed to vibrations of the external hydroxyls. The absorption bands observed at $3420-3445 \mathrm{~cm}^{-1}$ and at 2894 and $1633 \mathrm{~cm}^{-1}$ could be assigned to the $\mathrm{OH}$ vibration mode, which are observed in almost all the natural hydrous silicates. However, the $\mathrm{H}-\mathrm{O}-\mathrm{H}$ bending of water is observed at 1620 $-1642 \mathrm{~cm}^{-1}$ [17]. In the region of $1000-500 \mathrm{~cm}^{-1}$, vibration of the main functional groups of Si-O and Al-OH were observed. The band at around $1100-1010$ $\mathrm{cm}^{-1}$ is assigned to $\mathrm{Si}-\mathrm{O}$ stretching vibrations and the absorption bands at 914, 540 and $470 \mathrm{~cm}^{-1}$ are attributed to Si-O-Si bending vibration.

The doublet at $780-798 \mathrm{~cm}^{-1}$ is due to $\mathrm{Si}-\mathrm{O}-\mathrm{Si}$ inter tetrahedral bridging bonds in $\mathrm{SiO}_{2}$. The peaks identified at $936-914 \mathrm{~cm}^{-1}$ correspond to $\mathrm{Al}-\mathrm{OH}$ bending vibration in kaolinite [17] [18] [19]. The above-mentioned facts about the presence of calcium carbonate and kaolinite as impurities in cellulose samples confirm their origin from the used filler in paper making what corresponds to cellulose purity (Table 1).

\section{Conclusion}

This work presents the results of FTIR spectroscopic comparative study of two kinds of cellulosic fibers with reference sample of microcrystalline cellulose. Studying the chemical composition and FTIR spectra of six samples of cellulosic fibers from wood pulp and waste paper showed differences in organic components contents such as cellulose, hemicelluloses and lignin as well as in the presence of inorganic impurities (calcite and kaolinite) originating from filler in paper making. More detail characterizations of cellulose samples by using XRD, TG/DSC and SEM will be a subject of further research work.

\section{Acknowledgements}

The authors are grateful to the Slovak VEGA Grant Agency for financial support of the project VEGA 1/0277/15.

\section{References}

[1] Poletto, M., Ornaghi, H.L. and Zattera A.J. (2014) Native Cellulose: Structure, Cha- 
racterization and Thermal Properties. Materials, 7, 6105-6119. https://doi.org/10.3390/ma7096105

[2] Gutiérrez, A., del Río, J.C. and Martínez, A.T. (2009) Microbial and Enzymatic Control of Pitch in the Pulp and Paper Industry. Applied Microbiology and Biotechnology, 82, 1005-1018. https://doi.org/10.1007/s00253-009-1905-Z

[3] Rosa, M.F., Medeiros, E.S., Malmonge, J.A., Gregorski, K.S., Wood, D.F., Mattoso, L.H.C. and Imam, S.H. (2010) Cellulose Nanowhiskers from Coconut Husk Fibers: Effect of Preparation Conditions on Their Thermal and Morphological Behavior. Carbohydrate Polymers, 81, 83-92. https://doi.org/10.1016/j.carbpol.2010.01.059

[4] Ingrao, C., Bacenetti, J., Bezame, A., Blok, V., Geldermann, J., Goglio, P., Koukios, E.G., Lindner, M., Nemecek, T., Siracusa, V., Zabaniotou, A. and Huisingh, D. (2016) Agricultural and Forest Biomass for Food, Materials and Energy: Bio-Economy as the Cornerstone to Cleaner Production and More Sustainable Consumption Patterns for Accelerating the Transition towards Equitable, Sustainable, Post Fossil-Carbon Societies. Journal of Cleaner Production, 117, 4-6. https://doi.org/10.1016/j.jclepro.2015.12.066

[5] Ingrao, C., Lo Guidice, A., Bacenetti, J., Tricase, C., Dotelli, G., Fiala, M., Siracusa, V. and Mbohwa, C. (2015) Energy and Environmental Assessment of Industrial Hemp for Building Applications: A Review. Renewable and Sustainable Energy Reviews, 51, 29-42. https://doi.org/10.1016/j.rser.2015.06.002

[6] Mohr, B.J., Nanko, H. and Kurtis, K.E. (2005) Durability of Kraft Pulp Fiber-Cement Composites to Wet/Dry Cycling. Cement and Concrete Composites, 27, 435-448. https://doi.org/10.1016/j.cemconcomp.2004.07.006

[7] Ashori, A., Tabarsa, T. and Valizadeh, I. (2011) Fiber Reinforced Cement Boards Made from Recycled Newsprint Paper. Materials Science and Engineering: A, 528, 7801-7804. https://doi.org/10.1016/j.msea.2011.07.005

[8] Danial, W.H., Majid, Z.A., Muhid, M.N.M., Triwahyono, S., Bakar, M.B. and Ramli, Z. (2015) The Reuse of Wastepaper for the Extraction of Cellulose Nanocrystals. Carbohydrate Polymers, 118, 165-169. https://doi.org/10.1016/j.carbpol.2014.10.072

[9] Tucker, M.P., Nguyen, Q.A., Eddy, F.P., Kadam, K.L., Gedvilas, L.M. and Webb, J.D. (2001) Fourier Transform Infrared Quantitative Analysis of Sugars and Lignin in Pretreated Softwood Solid Residues. Applied Biochemistry and Biotechnology, 91, 51-61. https://doi.org/10.1385/ABAB:91-93:1-9:51

[10] Xu, F., Yu, J., Tesso, T., Dowell, F. and Wang, D. (2013) Qualitative and Quantitative Analysis of Lignocellulosic Biomass Using Infrared Techniques: A Mini-Review. Applied Energy, 104, 801-809. https://doi.org/10.1016/j.apenergy.2012.12.019

[11] Ahmad, Z., Iis, S., Halim, Z. and Sarifuddin, N. (2011) Effect of Fiber Length Variations on Properties of Coir Fiber Reinforced Cement-Albumen Composite (CFRCC). IIUM Engineering Journal, 12, 63-76.

[12] Stevulova, N., Cigasova, J., Estokova, A., Terpakova, E., Geffert, A., Kacik, F., Singovszka, E. and Holub, M. (2014) Properties Characterization of Chemically Modified Hemp Hurds. Materials, 7, 8131-8150. https://doi.org/10.3390/ma7128131

[13] Poletto, M., Pistor, V., Zeni, M. and Zattera, A.J. (2011) Crystalline Properties and Decomposition Kinetics of Cellulose Fibers in Wood Pulp Obtained by Two Pulping Processes. Polymer Degradation and Stability, 96, 679-685. https://doi.org/10.1016/j.polymdegradstab.2010.12.007

[14] Popescu, M.C., Popescu, C.M., Lisa, G. and Sakata, Z. (2011) Evaluation of Morphological and Chemical Aspects of Different Wood Species by Spectroscopy and 
Thermal Methods. Journal of Molecular Structure, 988, 65-72.

https://doi.org/10.1016/j.molstruc.2010.12.004

[15] Fackler, K., Stevanic, J.S., Ters, T., Hinterstoisser, B., Schwanninger, M. and Salmén, L. (2011) FT-IR Imaging Spectroscopy to Localise and Characterise Simultaneous and Selective White-Rot Decay within Sprude Woodcell. Holzforschung, 65, 411-420. https://doi.org/10.1515/hf.2011.048

[16] Lee, S., Kim, Y.J. and Moon H.S. (2003) Energy-Filtering Electron Microscopy (EF-TEM) Study of a Modulated Structure in Metakaolinite Represented by a $14 \AA$ Modulation. Journal of American Ceramic Society, 86, 174-176. https://doi.org/10.1111/j.1151-2916.2003.tb03297.x

[17] Saikia, B.J. and Parthasarathy, G. (2010) Fourier Transform Infrared Spectroscopic Characterization of Kaolinite from Assam and Meghalaya, Northeastern India. Journal of Modern Physics, 1, 206-210. https://doi.org/10.4236/jmp.2010.14031

[18] Rong, X., Huang, Q., He, X., Chen, H., Cai, P. and Liang, W. (2008) Interaction of Pseudomonas putida with Kaolinite and Montmorillonite: A Combination Study by Equilibrium Adsorption, ITC, SEM and FTIR. Colloids and Surfaces B: Biointerfaces, 64, 49-55. https://doi.org/10.1016/j.colsurfb.2008.01.008

[19] Madejová, J. (2003) FTIR Techniques in Clay Mineral Studies. Vibrational Spectroscopy, 31, 1-10. https://doi.org/10.1016/S0924-2031(02)00065-6 